\title{
Niche differentiation between a native and an invasive species of submersed macrophyte in a subtropical reservoir
}

\author{
Fernanda Moreira Florêncio ${ }^{1 *}$ (1), Márcio José Silveira' ${ }^{1}$ and Sidinei Magela Thomaz ${ }^{1}$ (C)
}

Received: July 13, 2020

Accepted: December 19, 2020

\begin{abstract}
Submersed macrophytes have important ecological roles but non-native invasive species may affect biodiversity and water uses. We investigated the native macrophyte Egeria najas and the invasive Hydrilla verticillata and measured their maximum colonization depth and its relationship with Secchi disk depth, their biomass along the depth gradient and their preferred depths of occurrence. The Itaipu Reservoir was monitored for seven years, during which maximum colonization depth and Secchi disk depth were measured. During a separate sampling, plants were collected to determine biomass along the depth gradient. Ancova showed that the maximum colonization depth of both species increased with increasing Secchi disk depth, but the maximum colonization depth of $H$. verticillata increased faster with increasing water transparency than did that of E. najas. Quadratic regression revealed that the biomass of each species peaks at intermediate depths. Hydrilla verticillata colonizes deeper regions than does E. najas. The patterns found in the present study can be explained by underwater light and, probably, wave disturbances. The preference of $H$. verticillata for deeper sites indicates that the ecological niches of the two macrophytes differ, and that $H$. verticillata has great potential to spread and accumulate biomass in reservoirs.
\end{abstract}

Keywords: colonization depth, depth occurrence, Hydrocaritaceae, invasive species, submerged macrophyte

\section{Introduction}

Invasive species are a cause of concern for ecologists and managers because new invasions are still increasing at accelerated rates (Seebens et al. 2017). These species may gradually replace the native ones, causing their extinction and homogenization of ecosystems, and altering nutrient cycles and energy fluxes (Mack \& Simberloff 2000; Agostinho et al. 2005; Espínola \& Junior 2007; Powell et al. 2011; Padial et al. 2020). Aquatic macrophytes have important roles in aquatic ecosystems (Gomes et al. 2012; Santos et al. 2020; Mabidi et al. 2020; Turunen et al. 2020). However, excessive growth of macrophytes can result in ecological and economic impacts (Marcondes 2003), which can be worse for invasive species since, in general, these species have traits that enhance their competitive ability and facilitate their growth and expansion (Gurovitch 2011; Rejmánek 2011; Sousa 2011; Silveira et al. 2018; Huang et al. 2019).

Aquatic macrophytes may colonize extensive areas in natural and artificial ecosystems (e.g., reservoirs). The extension of the colonization of rooted submersed aquatic macrophytes can be measured by their depth of occurrence (Chambers \& Kalff 1985; Thomaz \& Esteves 2011). Depth of occurrence may be influenced by several environmental factors, like underwater light, slope and organic matter

1 Laboratório de Macrófitas Aquáticas, Nupélia, Departamento de Biologia, Universidade Estadual de Maringá, 87020-900, Maringá, PR, Brazil

* Corresponding author: fmoreiraflorencio@gmail.com 
sediment, among others (Spence 1982; Duarte \& Kalff 1986; Thomaz 2002). However, underwater light is by far the most important determinant of the distribution and biomass of submersed macrophytes (Spence 1982; Sarvala et al. 2020). Its effect is more intense in deeper regions of lakes because in this situation, light intensity may not be sufficient for photosynthesis. The maximum colonization depth of macrophytes $\left(\mathrm{Z}_{\max }\right)$, for example, can be accurately predicted by underwater light intensity, which can be measured by Secchi disk transparency (Chambers \& Kalff 1985).

In contrast, minimum colonization $\operatorname{depth}\left(\mathrm{Z}_{\min }\right.$, i.e., the shallowest place a plant can colonize) is usually inversely proportional to wave action, because this factor represents a disturbance to organisms inhabiting the littoral zone (Spence 1982; Chambers \& Kalff 1987; Doyle 2001). Direct effects of waves on plants mainly include damage and uprooting of established individuals and the consequent reduction in plant survival (Doyle 2001). Because light limits $Z_{\max }$ and wave disturbance limits $Z_{\min }$, the colonization of submerged macrophytes can be favored in intermediate depths, compared to shallower and deeper zones (Spence 1982).

The most frequent rooted submersed macrophytes species in the Itaipu Reservoir of the Paraná River (Brazil/ Paraguay) are the native Egeria najas and the invasive Hydrilla verticillata, both Hydrocharitaceae (Mormul et al. 2010). Hydrilla verticillata is a highly invasive species that has reached all continents except Antarctica (Langeland 1996). In less than two years from its first record in the Paraná River, this species became the most frequent submersed macrophyte species in several habitats of the Upper Paraná River basin, including the arms of the Itaipu Reservoir (Thomaz et al. 2009; Souza et al. 2017). In high densities, $H$. verticillata can cause economic and ecological damages (Langeland 1996; Sousa 2011), especially because of some physiological distinctions (e.g., broad tolerances for environmental factors, which might include underwater light) (Sousa et al. 2009; Sousa 2011). For example, this invasive plant negatively affects the biomass of the native E. najas (Sousa 2011; Silveira et al. 2018). In situ monitoring of these two species becomes essential for predicting their distributions and high-density occurrences in reservoirs, for predicting future impacts of the invasive species over the native biota and to offer information for future management and conservation plans.

In this study we investigated the light and depth preferences of E. najas and $H$. verticillata. We tested the following hypotheses: (i) the $Z_{\max }$ of E. najas and $H$. verticillata is positively related to Secchi disk depth, but the responses of these species to this factor differ; (ii) both species have higher biomass in intermediate depths, and biomass decreases towards the shore (shallower zones) and the pelagic zone (deeper zones); and (iii) H. verticillata occurs in deeper zones than E. najas.

\section{Materials and methods}

\author{
Study area
}

The study was carried out in the Itaipu Reservoir of the Paraná River ( $24^{\circ} 15^{\prime} \mathrm{S}$ and $54^{\circ} 00^{\prime} \mathrm{W}$ ). The reservoir was flooded in 1982, has an area of $1,350 \mathrm{Km}^{2}$ and a residence time of approximately 40 days. Its eastern (Brazilian) shore (where our samplings were conducted) has eight main arms formed by tributaries, where we conducted the samplings to estimate $Z_{\max }$ (Fig. 1). Owing to its great area, Itaipu has long fetches, which affects macrophyte colonization (Thomaz et al. 2009).

The most frequent submersed macrophyte species in these arms are Egeria densa Planch., E. najas Planch, H. verticillata (L. f.) Royle and Nitella spp. (Mormul et al. 2010). These arms are characterized as meso- to eutrophic; other details about water physical and chemical features can be found in Thomaz et al. (2009).

\section{Relationship between Secchi disk depth and submersed macrophytes $Z_{\max }$}

We used data from a long-term survey to test the relationship between Secchi disk depth and $Z_{\max }$ [(hypothesis (i)]. Sampling occurred twice a year from 2008 to 2010, and from 2014 to 2017, for a total of 14 samples. Each sampling involved inspecting 230 to 235 georeferenced sampling stations on the Brazilian (eastern) side of the reservoir. Frequencies of $E$. najas and $H$. verticillata varied temporally and they occurred in less than $40 \%$ of the sites. On each sampling occasion, we determined $Z_{\max }$ at some sites where stands were well developed, indicating that the plants were established and subjected to local conditions for a relatively long period of time. We had a total of 110 $Z_{\max }$ values for E. najas and 86 for $H$. verticillata.

To measure $Z_{\max }$, we inspected sediment with a rake attached to a 4-m long aluminum pipe, in a transect perpendicular to the shore in search for the deepest occurrence of each species. $Z_{\max }$ occurs where there is the presence of small individuals $(<10 \mathrm{~cm})$, which marks the deepest limit of colonization. When macrophytes occurred in sites deeper than $4.0 \mathrm{~m}$, we searched the $Z_{\max }$ with a multiple hook attached to a rope. These two methods gave consistent results compared to measurements made with echo sound sonar (data not shown), making us confident in the results obtained with the rake and hook. The Secchi disk depth was also measured in the same places.

The data of $Z_{\max }$ obtained by the above method, along with the survey conducted in September 2018 (see below), were also used to test hypothesis (iii).

\section{Biomass of Egeria najas and Hydrilla verticillata along depth gradients}

The hypotheses (ii) and (iii) were tested with an additional sampling conducted in September 2018, when 


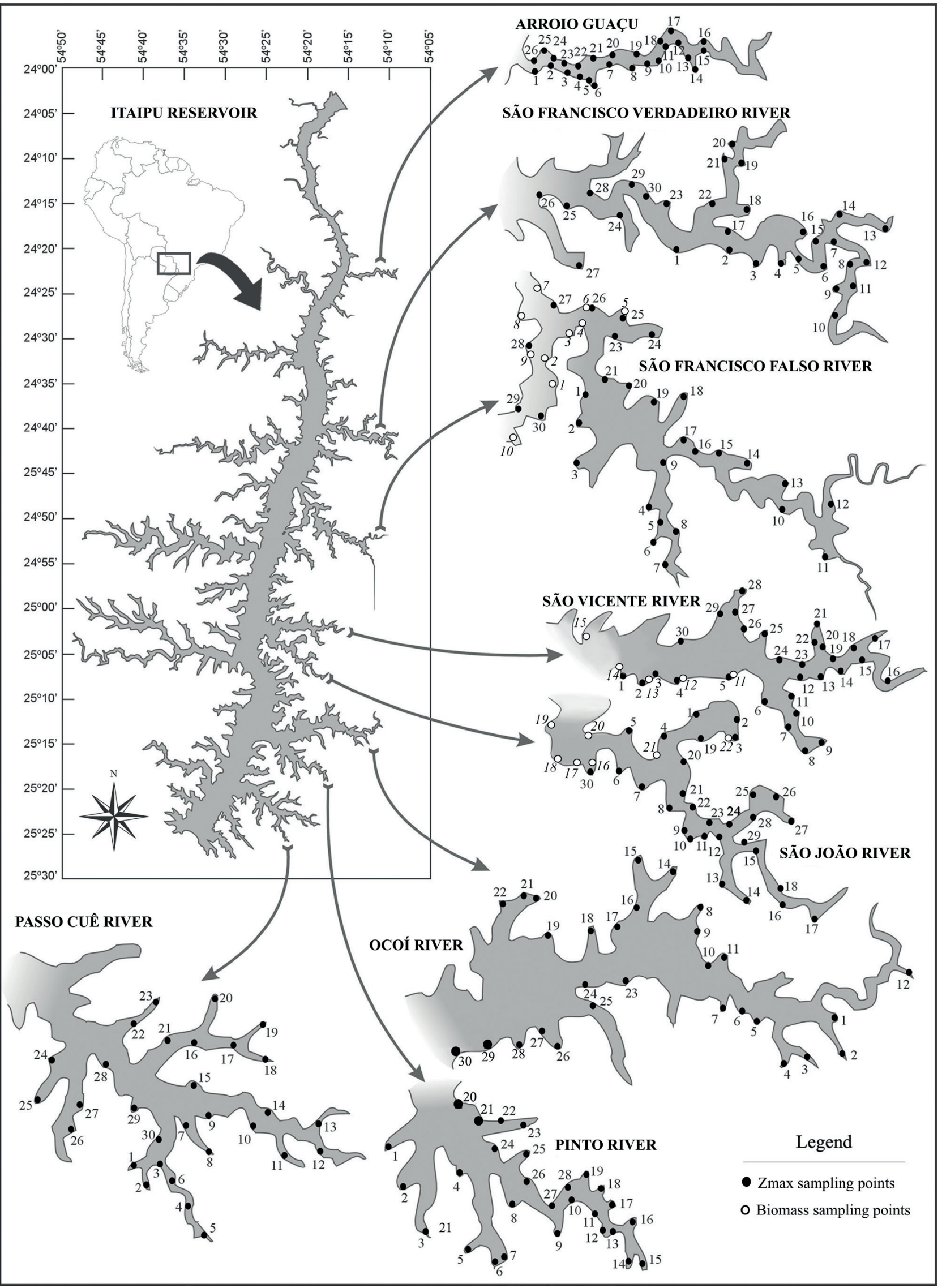

Figure 1. Map of the Itaipu Reservoir and its principal arms and sampling points of the long-term survey. 
we evaluated the biomass of both species at different depths. We sampled 22 sites during this sampling, 10 in the arm of the São Francisco Falso River, five in the arm of the São Vicente River and seven in the arm of the São João River (Fig. 1). We chose sites which fulfilled three conditions: (i) they should have stands with at least one of the mentioned species; (ii) the stands had to be well developed so as to allow sampling of different plant densities at different depths; and (iii) the stands should be dominated by one of the species under study. The second condition is important because sampling small stands (i.e., at the early stages of colonization) would not allow us to find a gradient of biomass along different depths, a condition necessary to test hypotheses (ii) and (iii). The third condition frees us from the following concerns: stands with several species could influence the biomass of the presented species because of possible competition among them, and a diverse community could affect the biomass sampled by each rake.

One transect of approximately $50 \mathrm{~m}$ (perpendicular to the shore) was established in each macrophyte stand and its position recorded using a GPS. Sampling was performed at five to seven points in each transect to measure macrophyte biomass, with depth also being measured at each of the points. We used a rake attached to a 4-m long aluminum pipe to sample biomass by positioning it in contact with the sediment, turning it $720^{\circ}$ and pulling it up. This method allows branches to get attached to the rake and, when pulled up, both below and aboveground biomass are harvested. The biomass collected at each point was washed in the field, stored in an individual plastic bag and then dried at $70^{\circ} \mathrm{C}$ until constant weight (dry weight; DW). Because we used the same protocol at all points, we expressed biomass values in $g$ DW per rake.

During this sampling, mean water temperature was $23.3^{\circ} \mathrm{C}(\mathrm{SD}=0.87)$, mean $\mathrm{pH}$ was $7.58(\mathrm{SD}=0.26)$, mean

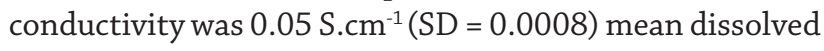
oxygen was $9.03 \mathrm{mg} \cdot \mathrm{L}^{-1}(\mathrm{SD}=0.60)$, mean turbidity was 2.73 UNT (SD = 2.08) and mean Secchi disk depth was $2.35 \mathrm{~m}$ $(S D=0.71)$. These water variables, with the exception of Secchi disk depth, were measured with a multi-parameter HORIBA sensor.

\section{Statistical analysis}

Hypothesis (i) was tested by Ancova, which was applied to log transformed data obtained from the sampling of 2008-2010 and 2014-2017 ( $\mathrm{N}=186)$. This analysis allowed assessing if $Z_{\max }$ is related to Secchi disk depth and if this relationship differs between species (E. najas and $H$. verticillata). The test was carried out with $\mathrm{R}$ software (R Development Core Team 2019), using the "tidyverse" (Wickham et al. 2019), "stats" (R Development Core Team 2019) and "car" (Fox \& Weisberg 2019) packages.

To test the relationship between the biomass of E. najas and $H$. verticillata and depth [hypothesis (ii)], we used $\log (x+1)$ transformed biomass data sampled in 2018.
A Polynomial Regression was used to test the relationship between the depth of each point (continuous predictor variable) and macrophyte DW (response variable). The polynomial model was chosen because we verified a quadratic trend in our data during a visual inspection of the biomass values along the depth gradient with a scatterplot. We used the following equation:

$$
\mathrm{Z}=\text { constant }+\mathrm{b}(\text { depth })+c\left(\text { depth }^{2}\right)
$$

where $Z$ is the DW of E. najas or H. verticillata, $b$ is the partial coefficient of the linear relationship between DW and depth and $c$ is the partial coefficient of the quadratic relationship between DW with depth. The analysis was performed in R software (R Development Core Team), using the "dplyr" package (Wickham et al. 2020).

We tested hypothesis (iii) using two strategies: first we compared $\mathrm{Z}_{\max }$ obtained in the long-term sampling; and second, we compared the depths of occurrence obtained in the 2018 survey. Both normality and homoscedasticity were met for $Z_{\max }$, so we used Anova to generate isolated models for each species. The Shapiro-Wilk test found that normality was not met by the depths of occurrence data measured in 2018, so we used the non-parametric Kruskal-Wallis test. Anova and the Kruskal-Wallis test were performed with Statistica $^{\mathrm{TM}} 7.1$ (StatSoft 2005).

\section{Results}

Ancova revealed that the relationship between $\mathrm{Z}_{\max }$ and Secchi disk depth depends significantly on the species (Secchi disk depth ${ }^{*}$ Species: $\left.F=8.15 ; P=0.004\right)$. The intercept of the fitted model of E. najas $\left(\alpha_{1}=0.84\right)$ is higher than the intercept for the model of $H$. verticillata $\left(\alpha_{2}=0.46\right)$, but the slope of the relationship between $Z_{\max }$ and Secchi disk depth for the latter $\left(\beta_{2}=0.49\right)$ is higher than that for the former $\left(\beta_{1}=0.24\right)$. This shows that while depth colonized by $E$. najas and $H$. verticillata increases with increasing water transparency, this response occurs at a greater extent for $H$. verticillata than for E. najas (see also trend lines crossing in Fig. 2).

From the biomass sampling conducted in 2018, the minimum depth reached by E. najas was $0.4 \mathrm{~m}$, the maximum depth was $3.0 \mathrm{~m}$ and the mean depth was $1.69 \mathrm{~m}$. The maximum biomass reached by $E$. najas was $144 \mathrm{~g}$ DW per rake, obtained at $1.20 \mathrm{~m}$ depth. For $H$. verticillata, the minimum depth was $1.00 \mathrm{~m}$, the maximum depth was $3.50 \mathrm{~m}$ and the mean depth was $2.43 \mathrm{~m}$. The maximum biomass reached for $H$. verticillata was $68 \mathrm{~g}$ DW per rake, obtained at a $1.50 \mathrm{~m}$ depth.

The quadratic model using depth as the predictor variable explained $28 \%$ of the variation in biomass for E. najas $\left(N=39 ; F_{2}=8.35 ; P=0.001\right)$ and $26 \%$ for $H$. verticillata $\left(N=26 ; F_{2}=5.46 ; P=0.01\right)$ (Tab. 1$)$. This relationship indicates that, for both species, an increase in biomass occurs with increasing depth, to a certain depth limit where biomass 
peaks, after which biomass values decrease significantly with increasing depth (Fig. 3). This result indicates that both species show a maximum biomass accumulation at intermediate depths. Comparison of the graphs for E. najas and $H$. verticillata reveals that the biomass curve for latter species is shifted to the right relative to the former. That is, $H$. verticillata reaches greater depths on average than E. najas, and its optimum point of growth, where the highest values of biomass are found, also tends to occur at greater depths.

The value of $Z_{\max }$ differed significantly between the species (Anova; $F=4.905, P=0.028$ ), evidencing that the invasive species is able to colonize deeper sites (mean = $4.11 \mathrm{~m} \pm 1.34$ ) than the native species (mean $=3.65 \mathrm{~m} \pm$ 1.03). The data from biomass sampling conducted in 2018 reveals that depth of occurrence also differed between the species (Kruskal-Wallis test; $X^{2}=3.895, P=0.04$ ), being higher for $H$. verticillata (mean $=2.43 \pm 0.82$ ) than E. najas (mean $=1.81 \mathrm{~m} \pm 0.92)$.

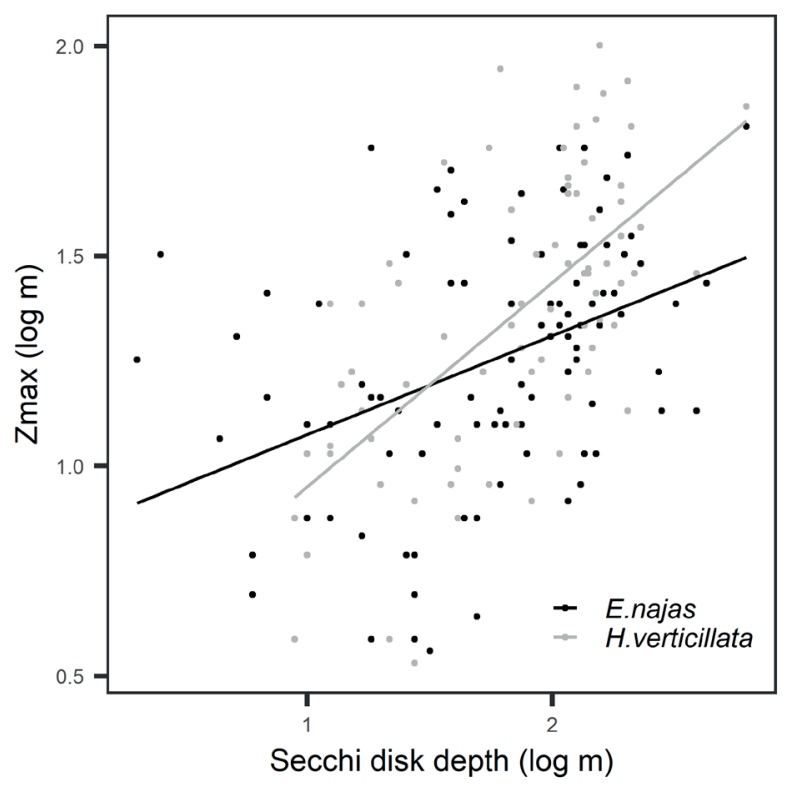

Figure 2. Relationship between the maximum colonization depth $\left(\mathrm{Z}_{\max }\right)$ of E. najas and $H$. verticillata and Secchi disk depth in the Itaipu Reservoir.

\section{Discussion}

Based on the results, our three hypotheses were corroborated. In fact, $Z_{\max }$ of both macrophyte species increased with increasing underwater light, and the responses of $Z_{\max }$ to Secchi depth differed between the two (Fig. 2). In addition, the abundance of both species peaks at intermediate depths (Fig. 3 ) and $H$. verticillata occurred in deeper zones than E. najas (Figs. 2 and 3). In general, these results support the importance of underwater light and, indirectly, the potential role of wave disturbances in determining the biomass gradients of the two investigated species, and that the native and invasive species differ in their responses to underwater light and water depth. Thus, our findings indicate that their niches related to use of light and depth colonization differ.

The results of the Ancova demonstrated that increased light availability increases $Z_{\max }$ of both species, while the comparison of the two species shows that at the same Secchi disk depth (for values $>1.5 \mathrm{~m}$ ), $H$. verticillata is able

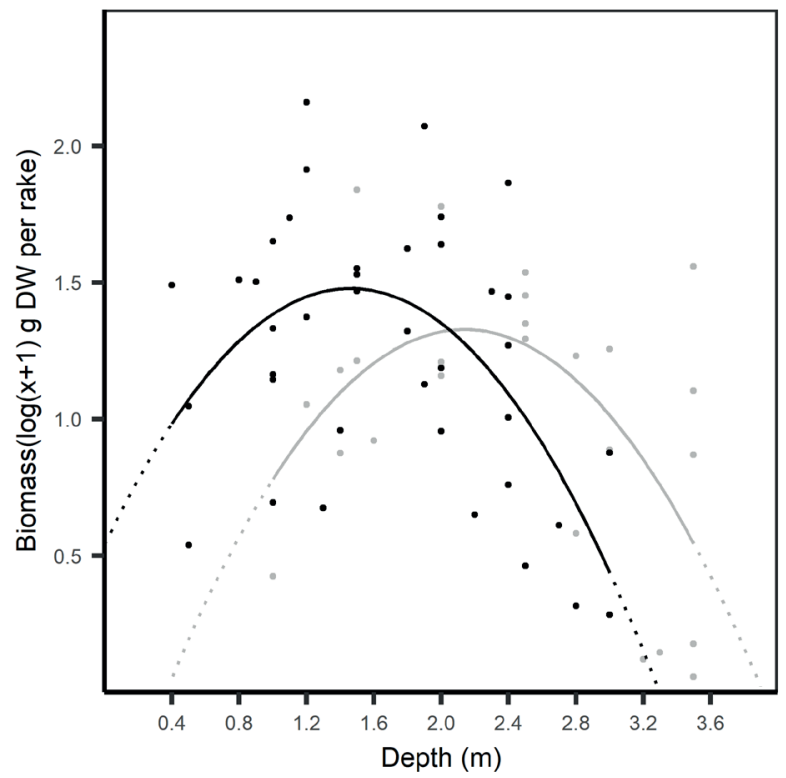

Figure 3. Relationship between a depth gradient and $\log (x+1)$ transformed dry biomass of E. najas (black line) and $H$. verticillata (grey line), using data collected in the Itaipu Reservoir in September 2018.

Table 1. Results of the Polynomial Regression Analysis assessing the effect of depth on Egeria najas and Hydrilla verticillata biomass ( $\mathrm{SE}=$ coefficient standard error; $\mathrm{t}=\mathrm{t}$-test to assess coefficient significance).

\begin{tabular}{|c|c|c|c|c|}
\hline & Coefficients & t & P \\
\hline Egeria najas & & & & 0.14 \\
\hline Intercept & 0.54 & 0.35 & 1.50 & 0.008 \\
\hline Depth & 1.28 & 0.45 & 2.80 & 0.001 \\
\hline Depth & -0.43 & 0.13 & -3.34 & \\
\hline Hydrilla verticillata & & & & 0.47 \\
\hline Intercept & -0.60 & 0.83 & -0.72 & 0.02 \\
\hline Depth & 1.80 & 0.75 & 2.39 & 0.01 \\
\hline Depth $^{2}$ & -0.42 & 0.15 & -2.68 & \\
\hline
\end{tabular}


to colonize deeper sites (higher $\mathrm{Z}_{\max }$ ) than E. najas (Fig. 2). The biomass samplings agree with these results, since it was evident that the biomass of the invasive species peaks in greater depths than the biomass of the native species (Fig. 3). $Z_{\max }$ is influenced mostly by suspended inorganic matter and phytoplankton, which negatively affect underwater light (Spence 1982; Chambers \& Kalff 1987). These factors together help explain the reduction of $Z_{\max }$ with reduced water transparency. In regard to differences between species, recent studies have shown that $H$. verticillata is able to regenerate from tubers and allocate resources for stem elongation rather than branch development under complete darkness (Huang et al. 2019), which helps explaining why $H$. verticillata is found at greater depths than E. najas.

At first glance, these findings contradict those recorded in the Upper Paraná floodplain and in experiments, which indicate that $H$. verticillata prefers sites with higher water transparency and less turbidity than E. najas (Sousa et al. 2009; Sousa 2011; Silveira 2015). In view of these previous data, $H$. verticillata would be expected to be found in shallower sites (where light intensity is higher) than E. najas. Thus, we infer that other factors may act in combination with transparency to explain the depth gradient of these two species in the Itaipu Reservoir. For example, organic matter sediment has been another important determinant of the success of these two species, with the invasive preferring less organic sediments (Sousa et al. 2009; Sousa 2011; Silveira \& Thomaz 2015). Shallow areas of the Itaipu Reservoir are highly colonized by macrophytes (Thomaz et al. 2009) and it is possible that organic matter accumulation in shallow areas prevents $H$. verticillata colonization in these areas. In addition, the set of variables that might act on the degree of colonization of deeper areas is much more complex, including the water flow velocity and differences in the chemical composition of the sediment (including nutrients and granulometry) between shallow and deep zones, for example (Duarte \& Kalff 1990; Chambers et al. 1991). Finally, other features peculiar to each species might also help to explain differences. For example, $H$. verticillata has faster root growth compared to other species of Hydrocaritaceae, which provide a very efficient anchoring system (Silveira et al. 2009). However, these possible explanations need further experimental exploration before any firm conclusions can be made in this regard.

The polynomial regression analysis showed that the growth of both species (indicated by biomass) is related with depth. Peak biomass for both species occurred at intermediate depths with biomass decreasing towards shore (shallower areas) and the pelagic zone (deeper areas). Decreased macrophyte biomass with increasing depth is explained by the same factors used to discuss $Z_{\max }$ : underwater light and, alternatively, sediment composition.

In contrast, factors other than light influence the decrease in biomass toward shallower areas. Although we did not directly measure wave disturbance, we infer that this is the main factor explaining decreased biomass toward shallower areas. Wave disturbance (wind generated) is one of the most important factors that prevents macrophyte colonization of shallow areas (Spence 1982; Chambers 1987), including in the Itaipu Reservoir (Thomaz et al. 2003; 2009). Wave disturbance reduces plant colonization and damages macrophyte tissues (Neiff et al. 2000; Doyle 2001; CunhaSantino et al. 2016). This damage reduces the colonization and plant biomass in places with greater wave impact, that is, in shallower places (Keddy 1982). Wave disturbance is directly related to fetch (distance at which the wind acts on the surface of a water body without obstruction), which in turn also affects macrophyte minimum colonization depth, since the higher the fetch, the greater the erosive potential of waves and, by extension, the greater the potential for macrophyte disturbance (Spence 1982). Despite suspecting that wave disturbance is the main factor responsible for decreased macrophyte biomass in shallower areas, we cannot discard other factors. For example, high light intensity may limit submersed plants in shallow sites (Jin et al. 2020). In addition, water level fluctuations and the presence of floating and emergent vegetation (common in Itaipu; Thomaz et al. 2009) may also have a role in decreased biomass toward the shores of the reservoir.

Our findings can be useful from a plant management perspective. Reservoirs usually have low water flow, high sedimentation and high water transparency (Barbosa et al. 1999), which favor the presence and proliferation of submerged vegetation, as we found in Itaipu. Manipulation of the water level is a tool that may be used in some reservoirs to control submerged plants (Thomaz 2002). Water level depletions could prevent infestations of submerged macrophytes, especially invasive species that are favored by the high-water transparency caused by impoundments. According to our results that evidence that $H$. verticillata prefers deeper sites, the control of infestations of this plant would need the use of greater water level depletions than would the control of native species, like E. najas. As the reservoirs are built to retain water, control of $H$. verticillata using water level manipulation becomes a challenge.

In summary, using long term data about $Z_{\max }$ and one sampling of macrophyte biomass, we show that the invasive $H$. verticillata and the native $E$. najas differ in depth preferences, with the former preferring deeper sites. We also found that the biomass of both species peaks at intermediate depths and that the biomass of $H$. veriticillata peaks at greater depths than the biomass of E. najas. Thus, our field data suggest the niches of these two species (in terms of light use and depth colonization), differ. The patterns we found are related to limitations of underwater light toward deeper areas and probably wave disturbance in shallower areas, although other factors like light saturation and presence of macrophytes along the shores may also play a role in the depth gradients we found. Finally, the success of $H$. verticillata in deeper areas indicates that this 
species is able to escape from wave disturbances (which occur mainly in shallow areas) and may succeed and cause damage in large reservoirs. Experimental studies about the colonization and growth phases of these species at different depths, and subjected to a gradient of disturbances caused by waves, would bring important contributions to explain the mechanisms involved in the patterns we detected in situ.

\section{Acknowledgements}

We acknowledge, with appreciation, two anonymous referees for their insightful comments, which improved our manuscript. FM Florêncio and MJ Silveira acknowledge $\mathrm{CNPq}$ for providing a MSc and a post-doc scholarship, respectively. SM Thomaz thanks CNPq for continuous funding through a Research Productivity Grant. We also acknowledge Itaipu Binacional by funding our samplings.

\section{References}

Agostinho AA, Thomaz SM, Gomes LC. 2005. Conservação da biodiversidade em águas continentais do Brasil. Megadiversidade 1: 70-78.

Barbosa FAR, Padisák J, Espíndola ELG, Borics G, Rocha O. 1999. The cascading reservoir continuum concept (CRCC) and its application to the river Tietê-basin, São Paulo State, Brazil. In: Straskraba M, Tundisi JG. (eds.) Theoretical Reservoir Ecology and Its Applications. São Carlos, International Institute of Ecology. p. 425-438.

Chambers PA, Kalff J. 1985. Depth distribution and biomass of submersed aquatic macrophyte communities in relation to Secchi depth. Canadian Journal of Fisheries and Aquatic Sciences 42: 701-709.

Chambers PA, Kalff J. 1987. Light and nutrients in the control of aquatic plant community structure. I. In situ experiments. The Journal of Ecology 75: 611-619.

Chambers PA, Prepas EE, Hamilton HR, Bothwell ML. 1991. Current velocity and its effect on aquatic macrophytes in flowing waters. Ecological Applications 1: 249-257.

Chambers PA. 1987. Nearshore occurrence of submersed aquatic macrophytes in relation to wave action. Canadian Journal of Fisheries and Aquatic Sciences 44: 1666-1669.

Cunha-Santino MB, Fushita AT, Peret AC, Bianchini-Junior I. 2016. Morphometry and retention time as forcing functions to establishment and maintenance of aquatic macrophytes in a tropical reservoir. Brazilian Journal of Biology 76: 673-685.

Doyle RD. 2001. Effects of waves on the early growth of Vallisneria americana. Freshwater Biology 46: 389-397.

Duarte CM, Kalff J. 1986. Littoral slope as a predictor of the maximum biomass of submerged macrophyte communities. Limnology and Oceanography 31: 1072-1080.

Duarte CM, Kalff J. 1990. Patterns in the submerged macrophyte biomass of lakes and the importance of the scale of analysis in the interpretation. Canadian Journal of Fisheries and Aquatic Sciences 47: 357-363.

Espínola LA, Junior HFJ. 2007. Invader species: concepts, models and attributes. Interciencia 32: 580-585.

Fox J, Weisberg S. 2019. An \{R\} Companion to Applied Regression. Sage. https://socialsiences.mcmaster.ca/jfox/Books/Companion/. 27 Jun. 2019.

Gomes LC, Bulla CK, Agostinho AA, Vasconcelos LP, Miranda LE. 2012. Fish assemblage dynamics in a Neotropical floodplain relative to aquatic macrophytes and the homogenizing effect of a flood pulse. Hydrobiologia 685: 97-107.

Gurovitch J. 2011. Competition, plants. In: Simberloff D, Rejmánek M. (eds.) Encyclopedia of Biological Invasions. Berkeley, University of California Press. p. 122-125
Huang XL, Xu X, Liu SL, et al. 2019. Impact of eutrophication on root morphological and topological performance in free-floating invasive and native plant species. Hydrobiologia 836: 123-139.

Jin S, Ibrahim M, Muhammad S, Khan S, Li G. 2020. Light intensity effects on the growth and biomass production of submerged macrophytes in different water strata. Arabian Journal of Geosciences 13: 1-7.

Keddy PA. 1982. Quantifying within-lake gradients of wave energy: interrelationships of wave energy, substrate particle size and shoreline plants in Axe Lake, Ontario. Aquatic Botany 14: 41-58.

Langeland KA. 1996. Hydrilla tuber formation in response to single and sequential bensulfuron methyl exposures at different times. In: Caffrey JM, Barrett PRF, Murphy KJ, Wade PM. (eds.) Management and Ecology of Freshwater Plants. Dordrecht, Springer. p. 247-251.

Mabidi A, Bird MS, Perissionotto R. 2020. Relationships between vegetation cover (Schoenoplectus decipiens) and wetland macroinvertebrate assemblages in a semi-arid landscape (Eastern Cape Karoo, South Africa). Hydrobiologia 847: 2049-2064.

Mack RN, Simberloff D. 2000. Biotic invasions: causes, epidemiology, global consequences, and control. Ecological Applications 10: 689-710.

Marcondes DAS. 2003. Estudos para manejo integrado de plantas aquáticas no reservatório de Jupiá. In: Thomaz SM, Bini LM. (eds.) Ecologia e manejo de macrófitas aquáticas. Maringá, Editora da Universidade Estadual de Maringá - Eduem. p. 264-280.

Mormul RP, Ferreira FA, Michelan TS, Carvalho P, Silveira MJ, Thomaz SM. 2010. Aquatic macrophytes in the large, sub-tropical Itaipu Reservoir, Brazil. Revista de Biología Tropical 58: 1437-1451.

Neiff JJ, Poin de Neiff ASG, Patiño CAE, de Chiozzi B. 2000. Prediction of colonization by macrophytes in the Yaciretá Reservoir of the Paraná River (Argentina and Paraguay). Revista Brasileira de Biologia 60: 615-626.

Padial AA, Vitule JRS, Olden JD. 2020. Preface: aquatic homogenoceneunderstanding the era of biological re-shuffling in aquatic ecosystems. Hydrobiologia 847: 3705-3709.

Powell KI, Chase JM, Knight TM. 2011. A synthesis of plant invasion effects on biodiversity across spatial scales. American Journal of Botany 98: 539-548.

R Development Core Team. 2019. R: A language and environment for statistical computing. R Foundation for Statistical Computing, Vienna, Austria. https://www.R-project.org/. 17 Jun. 2019.

Rejmánek M. 2011. Invasiveness. In: Simberloff D, Rejmánek M. (eds.) Encyclopedia of Biological Invasions. Berkeley, University of California Press. p. 379-385.

Santos NG, Stephan LR, Otero A, Iglesias C, Castilho-Noll MSM. 2020. How free-floating macrophytes influence interactions between planktivorous fish and zooplankton in tropical environments? An in-lake mesocosm approach. Hydrobiologia 847: 1357-1370.

Sarvala J, Helminen H, Heikkilä J. 2020. Invasive submerged macrophytes complicate management of a shallow boreal lake: a 42-year history of monitoring and restoration attempts in Littoistenjärvi, SW Finland. Hydrobiologia (in press). doi: 10.100/s10750-020-04318-7

Seebens H, Blackburn TM, Dyer EE, et al. 2017. No saturation in the accumulation of alien species worldwide. Nature Communications 8: 1-9.

Silveira MA, Thomaz SM, Mormul RP, Camacho FP. 2009. Effects of desiccation and sediment type on early regeneration of plant fragments of three species of aquatic macrophytes. International Review of Hydrobiology 94: 169-178.

Silveira MJ, Alves DC, Thomaz SM. 2018. Effects of the density of the invasive macrophyte Hydrilla verticillata and root competition on growth of one native macrophyte in different sediment fertilities. Ecological Research 33: 924-934.

Silveira MJ, Thomaz SM. 2015. Growth of a native versus an invasive submerged aquatic macrophyte differs in relation to mud and organic matter concentrations in sediment. Aquatic Botany 124: 85-91.

Silveira MJ. 2015. The effect of habitat and sediment type on the occurrence of non-native and native species of aquatic macrophyte in subtropical regions. Bioscience Journal 31: 1. doi: 10.14393/BJv31n1a2015-22305 
Sousa WTZ, Thomaz SM, Murphy KJ, Silveira MJ, Mormul RP. 2009. Environmental predictors of the occurrence of exotic Hydrilla verticillata (Lf) Royle and native Egeria najas Planch. in a sub-tropical river floodplain: the Upper River Paraná, Brazil. Hydrobiologia 632: 65-78. Sousa WTZ. 2011. Hydrilla verticillata (Hydrocharitaceae), a recent invader threatening Brazil's freshwater environments: a review of the extent of the problem. Hydrobiologia 669: 1-20.

Souza DC, Cunha ER, Murillo RDA, et al. 2017. Species inventory of aquatic macrophytes in the last undammed stretch of the Upper Paraná River, Brazil. Acta Limnologica Brasiliensia 29. doi: 10.1590/ S2179-975X6017

Spence DHN. 1982. The zonation of plants in freshwater lakes. Advances in Ecological Research 12: 37-125.

StatSoft I. 2005. STATISTICA (data analysis software system). Version 7.1. www.statsoft.com. 17 Jun.2019.

Thomaz SM, Carvalho P, Mormul RP, Ferreira FA, Silveira MJ, Michelan TS. 2009. Temporal trends and effects of diversity on occurrence of exotic macrophytes in a large reservoir. Acta Oecologica 35: 614-620.
Thomaz SM, Esteves FA. 2011. Comunidade de macrófitas aquáticas. In. Esteves FA. (ed.) Fundamentos de limnologia. Rio de Janeiro, Interciência. p. 461-518.

Thomaz SM. 2002. Fatores ecológicos associados à colonização e ao desenvolvimento de macrófitas aquáticas e desafios de manejo. Planta Daninha 20: 21-33.

Thomaz, SM, Souza, DC, Bini, LM. 2003. Species richness and beta diversity of aquatic macrophytes in a large subtropical reservoir (Itaipu Reservoir, Brazil): the influence of limnology and morphometry. Hydrobiologia 505: 119-128.

Turunen J, Muotka T, Aroviita J. 2020. Aquatic bryophytes play a key role in sediment-stressed boreal headwater streams. Hydrobiologia 847: 605-615.

Wickham H, Averick M, Bryan J, et al. 2019. Welcome to the tidyverse. Journal of Open Source Software 4: 1686. doi: 10.21105/joss. 01686

Wickham H, François R, Henry L, Muller K. 2020. Dplyr: A Grammar of Data Manipulation. R package version 1.0.0. https://CRAN.R-project. org/package=dplyr. 17 Jun. 2019. 